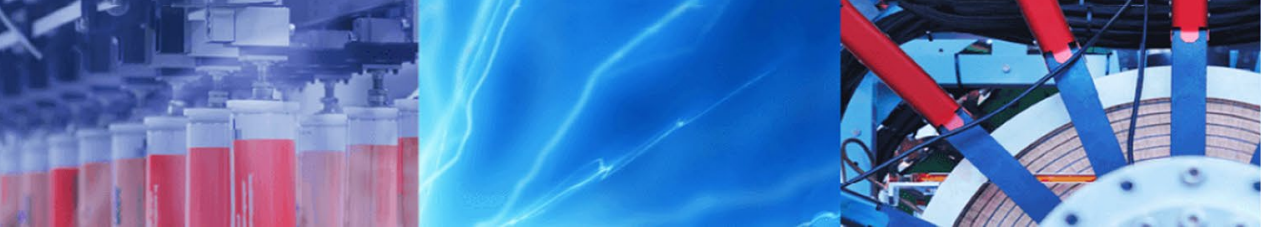

Research Article

\title{
Optimization of persulfate/iron(II)/UV-A irradiation process for the treatment of landfill leachate from Fez City (Morocco)
}

\author{
Imane El Mrabet ${ }^{1}$ (D) $\cdot$ Mourad Benzina $^{2} \cdot$ Hicham Zaitan $^{1}$ (D)
}

Received: 15 October 2019 / Accepted: 3 May 2020 / Published online: 9 May 2020

(c) Springer Nature Switzerland AG 2020

\begin{abstract}
The objective of this study is to investigate the efficiency of the advanced oxidation process using persulfate ions $\mathrm{S}_{2} \mathrm{O}_{8}{ }^{2-}(\mathrm{PS}), \mathrm{Fe}^{2+}$, and UV-A irradiation for the treatment of stabilized leachate from the urban sanitary landfill of Fez city (Morocco). In fact, in the presence of an activating agent, $\mathrm{S}_{2} \mathrm{O}_{8}{ }^{2-}$ generates sulfate radicals $\left(\mathrm{SO}_{4}{ }^{-}\right.$) which are powerful oxidizers for organic matter. The effect of reaction time, $\mathrm{PS}$ and $\mathrm{Fe}^{2+}$ dosage on the raw landfill leachate treatment was evaluated to define the optimum operational conditions according to chemical oxygen demand (COD) and color removal. Hence, the optimization of these process parameters led to a maximal removal of COD (70\%) and color (94\%) using $\mathrm{S}_{2} \mathrm{O}_{8}{ }^{2-}$ dose $=14,000 \mathrm{mg} \mathrm{L}^{-1}, \mathrm{Fe}^{2+}$ dose $=1600 \mathrm{mg} \mathrm{L}^{-1}$, and $\mathrm{pH}=3$ under $60 \mathrm{~min}$ of UV-A irradiation. The application of UV-A had a positive effect on the treatment efficiency, $\mathrm{PS} / \mathrm{Fe}^{2+} / \mathrm{UV}-\mathrm{A}$ has indeed enhanced COD removal by (+10\%) compared with $\mathrm{PS} / \mathrm{Fe}^{2+}$ only. The results of this study showed that the oxidative system ( $\left.\mathrm{PS} / \mathrm{Fe}^{2+} / \mathrm{UV}-\mathrm{A}\right)$ can achieve a high level of COD and color removal from landfill leachate. Consequently, the high efficiency, the easy use, and the fast mechanism could make this system as a promising and alternative process for landfill leachate and wastewater treatment.
\end{abstract}

Keywords Chemical oxidation · Activated-persulfate $\cdot U V-A \cdot$ Leachate treatment - Organic pollutants

\section{Introduction}

Landfill leachate is defined as the effluent generated by rainwater percolation through landfilled solid waste. Thus, leachate is bad-smelling, blackish, and loaded with various and complex pollutants. This justifies the considerable attention paid to solve this issue through several studies developing different treatment processes applied to real or synthetic effluents [1-5].

In the last few years there has been a growing interest in advanced oxidation processes (AOPs) as efficient methods for pollutants removal from aqueous phases [6]. For instance, Fenton, photo-Fenton [7], Fenton-Like [8], ozonation [9] and UV irradiations [10] processes, mostly applied, are based on the generation of hydroxyl radicals $(\cdot \mathrm{OH})$ which has a high standard oxidation potential $\left(\mathrm{E}^{\circ} \approx\right.$ $2.8 \mathrm{~V}$ at $25^{\circ} \mathrm{C}$ ) [6].

In addition, persulfate $\left(\mathrm{S}_{2} \mathrm{O}_{8}{ }^{2-}\right)$ is one of the strong oxidants widely used in the degradation of various organic contaminants from the water and wastewater. In fact, despite its disadvantages, such as the narrow working $\mathrm{pH}$ range, the high cost, the production of intermediate pollutants, and the iron sludge production in the case of $\mathrm{Fe}^{2+}$ as a catalyst, previous studies have proved that PS was successfully applied in different oxidative systems (Ozone/ PS, UV/PS, Microwave/PS, Iron/PS, Aluminum/PS) for COD removal from landfill leachate [11-15]. Actually, this effectiveness is due to its high chemical reactivity, stability, and wide $\mathrm{pH}$ range in liquid phases. Moreover, it is known by a high standard oxidation potential $\left(E^{\circ}=2.01 \mathrm{~V}\right)[16,17]$ and

$\triangle$ Imane El Mrabet, imane.elmrabet@usmba.ac.ma; $₫$ Hicham Zaitan, hicham.zaitan@usmba.ac.ma| ${ }^{1}$ Processes, Materials and Environment Laboratory (LPME), Department of Chemistry, Faculty of Sciences and Technology of Fez, Sidi Mohamed Ben Abdellah University, Fez, Morocco. 'Laboratory "Water, Energy and Environment” (LR3E), National Engineering School of Sfax, University of Sfax, Sfax, Tunisia. 
ability to initiate sulfate radical $\left(\mathrm{SO}_{4}^{--}\right)$which has a high oxidizer effect for organic compounds degradation because of its important oxidation potential $\left(E^{\circ}=2.7 \mathrm{~V}\right)$ [18]. These sulfate radicals are generated throughout persulfate activation which initiated by various processes such as heat energy, exposition to UV irradiation or addition of transition metals [19-21], according to the following Eqs. (1-3):

$\mathrm{S}_{2} \mathrm{O}_{8}^{2-}+$ heat $\rightarrow 2 \mathrm{SO}_{4}^{--}$

$\mathrm{S}_{2} \mathrm{O}_{8}^{2-}+\mathrm{Mn}^{\mathrm{n}+} \rightarrow \mathrm{Mn}^{\mathrm{n}+1}+\mathrm{SO}_{4}^{2-}+\mathrm{SO}_{4}^{-}$

$\mathrm{S}_{2} \mathrm{O}_{8}^{2-}+\mathrm{h} v \rightarrow 2 \mathrm{SO}_{4}^{-}$

In Morocco, landfill leachate issues are gaining increasing importance, where dozens of research works have been conducted on the characterization and the treatment of this effluent sampled from different municipal landfills of Moroccan cities. However, the majority of these studies applied mainly coagulation-flocculation and biological as processes treatment [22-24]. To our knowledge, the application of $\mathrm{PS} / \mathrm{Fe}^{2+} / \mathrm{UV}$ for the treatment of landfill leachates has not been reported elsewhere. Hence, the current work is considered as the first study that applies simultaneously PS, $\mathrm{Fe}^{2+}$ and UV irradiations in landfill leachate treatment.

Therefore, this study aims (a) to compare the application $\mathrm{S}_{2} \mathrm{O}_{8}{ }^{2-} / \mathrm{Fe}^{2+}$ and $\mathrm{S}_{2} \mathrm{O}_{8}{ }^{2-} / \mathrm{Fe}^{2+} / \mathrm{UV}-\mathrm{A}$ systems for the treatment of Fez city landfill leachate with respect to $C O D$ and color removal and (b) to evaluate the effects of PS, iron dosages and reaction time on COD and color elimination.

\section{Experiments}

\subsection{Chemicals and reagents}

Potassium persulfate $\left(\mathrm{K}_{2} \mathrm{~S}_{2} \mathrm{O}_{8}\right)$, ferrous sulfate $\left(\mathrm{FeSO}_{4} * 7 \mathrm{H}_{2} \mathrm{O}\right)$, sulfuric acid $\left(\mathrm{H}_{2} \mathrm{SO}_{4}\right)$ and sodium hydroxide $(\mathrm{NaOH})$ were purchased from Sigma-Aldrich chemicals (St. Louis, Missouri, USA).

\subsection{Leachate sampling and characterization}

The leachate used in this study was obtained from municipal solid waste landfill (MSWL) located at $11 \mathrm{~km}$ from Fez city, Morocco. This landfill receives 1000 tons of solid waste per year and generates about $350-450 \mathrm{~m}^{3}$ of leachate per day. The raw leachate was sampled in opaque plastic bottles, transported immediately to the laboratory, and stored in the dark at $4{ }^{\circ} \mathrm{C}$ in order to prevent any biological or chemical reactions. Thereafter, the physical-chemical parameters of the sample were measured: temperature, $\mathrm{pH}$, electrical conductivity, turbidity, TSS (total suspended solid), $\mathrm{COD}, \mathrm{BOD}_{5}$ (biological oxygen demand), nitrates, nitrites, sulfates, in accordance with the standard methods previously used in a published study [7]. The main characteristic parameters of landfill leachate are shown in Table 1. It is noticed that the studied leachate is highly loaded with different pollutants, expressed by high values of TSS, turbidity, $\mathrm{COD}, \mathrm{BOD}_{5}$, and color number. Moreover, the $\mathrm{pH}$ value $(>7.5)$ and $\mathrm{BOD}_{5} / \mathrm{COD}$ ratio $(<0.1)$ reveal that this sample has a low biodegradability and could be designated as stabilized leachate. Consequently, the refractory substances of this leachate could be effectively removed using physical-chemical processes $[25,26]$.

\subsection{Procedure of leachate treatment}

Potassium persulfate $\left(\mathrm{K}_{2} \mathrm{~S}_{2} \mathrm{O}_{8}\right)$ was used as a source of $\mathrm{S}_{2} \mathrm{O}_{8}{ }^{2-}$, while $\mathrm{Fe}^{2+}$ ions were provided by ferrous sulfate $\left(\mathrm{FeSO}_{4}{ }^{*} 7 \mathrm{H}_{2} \mathrm{O}\right)$, and $\mathrm{pH}$ leachate was adjusted using $2 \mathrm{M}$ $\mathrm{H}_{2} \mathrm{SO}_{4}$ or $2 \mathrm{M} \mathrm{NaOH}$.

The leachate treatment tests were conducted at ambient temperature in batch mode, under magnetic stirring of $\mathrm{K}_{2} \mathrm{~S}_{2} \mathrm{O}_{8}$ and $\mathrm{FeSO}_{4}$ amounts added to a volume of raw leachate. Firstly, the preliminary experiments were carried out in a cylindrical pyrex photoreactor in order to fix the initial $\mathrm{pH}$ of leachate and to determine the range of $\mathrm{S}_{2} \mathrm{O}_{8}{ }^{2-}$ and $\mathrm{Fe}^{2+}$ dosages. Thereafter, the contact time effect

Table 1 Physico-chemical characteristics of landfill leachate from Fez city

\begin{tabular}{|c|c|c|}
\hline Parameters & Unit & Value \\
\hline Electrical conductivity & $\mathrm{mS} \mathrm{cm} \mathrm{cm}^{-1}$ & 34 \\
\hline $\mathrm{T}$ & ${ }^{\circ} \mathrm{C}$ & 24 \\
\hline $\mathrm{pH}$ & - & 8 \\
\hline TSS & $\mathrm{mg} \mathrm{L}^{-1}$ & 14,000 \\
\hline Turbidity & NTU & 218 \\
\hline COD & $\mathrm{mg} \mathrm{O}_{2} \mathrm{~L}^{-1}$ & 5198 \\
\hline $\mathrm{BOD}_{5}$ & $\mathrm{mg} \mathrm{O}_{2} \mathrm{~L}^{-1}$ & 500 \\
\hline $\mathrm{BOD}_{5} / \mathrm{COD}$ & - & 0.09 \\
\hline Color number & - & 6.52 \\
\hline $\mathrm{SO}_{4}^{2-}$ & $\mathrm{mg} \mathrm{L}^{-1}$ & 140 \\
\hline $\mathrm{NO}_{3}^{-}$ & $\mathrm{mg} \mathrm{L}^{-1}$ & 8.13 \\
\hline $\mathrm{NO}_{2}^{-}$ & $\mathrm{mg} \mathrm{L}^{-1}$ & 7.15 \\
\hline $\mathrm{Cl}^{-}$ & $\mathrm{mg} \mathrm{L}^{-1}$ & 6845 \\
\hline $\mathrm{SO}_{4}{ }^{2-}$ & $\mathrm{mg} \mathrm{L}^{-1}$ & 140 \\
\hline $\mathrm{Cr}$ & $\mathrm{mg} \mathrm{Cr} \mathrm{L}^{-1}$ & 1.74 \\
\hline $\mathrm{Cu}$ & $\mathrm{mg} \mathrm{Cu} \mathrm{L}^{-1}$ & 0.05 \\
\hline $\mathrm{Fe}$ & $\mathrm{mg} \mathrm{Fe} \mathrm{L}^{-1}$ & 1.83 \\
\hline $\mathrm{Mn}$ & $\mathrm{mg} \mathrm{Mn} \mathrm{L}^{-1}$ & 0.043 \\
\hline $\mathrm{Zn}$ & $\mathrm{mg} \mathrm{Zn} \mathrm{L^{-1 }}$ & 0.2 \\
\hline
\end{tabular}


was investigated under fixed values of $\mathrm{pH}, \mathrm{S}_{2} \mathrm{O}_{8}{ }^{2-}$ and $\mathrm{Fe}^{2+}$ concentration. A volume of $5 \mathrm{~mL}$ of the sample was collected at regular time intervals of the treatment and centrifuged for $10 \mathrm{~min}$ at $5000 \mathrm{rpm}$ for the UV-visible spectrophotometry analysis and COD measurements. Afterwards, the effect of $\mathrm{S}_{2} \mathrm{O}_{8}{ }^{2-}$ dosage was studied at optimal $\mathrm{pH}$ and contact time. Finally, $\mathrm{Fe}^{2+}$ dosage was selected under the optimal conditions of $\mathrm{pH}$, contact time and $\mathrm{S}_{2} \mathrm{O}_{8}{ }^{2-}$ concentration. The optimal parameters values were obtained based on the best performances in terms of COD removal and UV-Visible spectra variation, which were measured for each sample at different points of the parameter range.

Nevertheless, to study the effect of UV-A irradiations, the same procedure was followed under the light of three UV-A lamps of (20 W, $365 \mathrm{~nm})$ in the same photoreactor (Fig. 1) [5].

COD removal was calculated using the following formula:

$\operatorname{COD}$ removal $(\%)=\frac{\mathrm{COD}_{\mathrm{i}}-\mathrm{COD}_{\mathrm{f}}}{\mathrm{COD}_{\mathrm{i}}} \times 100$

where $\mathrm{COD}_{\mathrm{i}}$ and $\mathrm{COD}_{\mathrm{f}}$ are $\mathrm{COD}$ of raw and treated leachate, respectively.

Color number (CN) was calculated using a formula related to the measurement of absorbance values at three wavelengths $436 \mathrm{~nm}, 525 \mathrm{~nm}$, and $620 \mathrm{~nm}$ (5) [27].

$\mathrm{CN}=\frac{\mathrm{SAC}_{436}^{2}+\mathrm{SAC}_{525}^{2}+\mathrm{SAC}_{620}^{2}}{\mathrm{SAC}_{436}+\mathrm{SAC}_{525}+\mathrm{SAC}_{620}}$

$\mathrm{SAC}_{\mathrm{i}}=\frac{\mathrm{Abs}_{\mathrm{i}}}{\mathrm{x}}$

With SAC is the spectral absorption coefficient at each wavelength, and $\mathrm{x}$ is the thickness of the used cell.

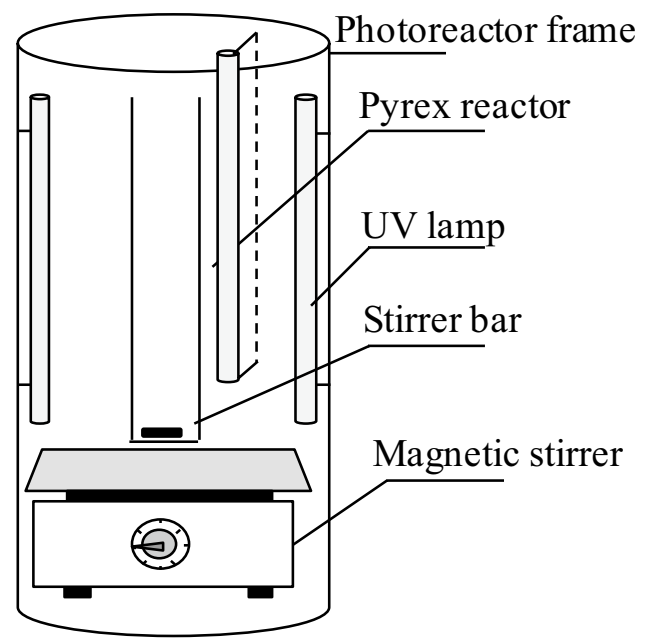

Fig. 1 Schematic of photoreactor with suspended UV-A lamps

\section{Results and discussion}

In order to evaluate the efficiency of PS/Fe ${ }^{2+}$ and PS/ $\mathrm{Fe}^{2+} / \mathrm{UV}-\mathrm{A}$ treatments, the reaction time effect was initially investigated. Afterwards, COD removal and UV-Vis spectrum were carried out as a function of $\mathrm{PS}$ and $\mathrm{Fe}^{2+}$ dosage under optimal values of $\mathrm{pH}$ and reaction time. It should be noted that preliminary tests were performed with the aim of choosing the PS and $\mathrm{Fe}^{2+}$ dose range and fixing $\mathrm{pH}$ at 3.

\subsection{Contact time effect}

The reaction time was examined from 5 to $120 \mathrm{~min}$ at fixed $\mathrm{pH}, \mathrm{PS}$, and $\mathrm{Fe}^{2+}$ dosage $\left(\mathrm{pH}=3\right.$; $[\mathrm{PS}]=3000 \mathrm{mg} \mathrm{L}^{-1}$; $\left.\left[\mathrm{Fe}^{2+}\right]=1000 \mathrm{mg} \mathrm{L}^{-1}\right)$. Figure 2 illustrates the COD removal evolution depending on reaction time, under fixed amounts of $\mathrm{PS}, \mathrm{Fe}^{2+}$, and $\mathrm{pH}$ value. Curve displayed in Fig. 2 indicates that the COD removal increases rapidly with the reaction time, where $46 \%$ of COD was reduced in the first $5 \mathrm{~min}$. After that, the efficiency gradually becomes slow and reaches the maximal removal $(\approx 62 \%)$ after $60 \mathrm{~min}$. These results could be explained by the consumption of $\mathrm{S}_{2} \mathrm{O}_{8}{ }^{2-}$ and $\mathrm{Fe}^{2+}$ with reaction time [13, 28] and allow to choose $60 \mathrm{~min}$ as the optimal contact time, and that was selected for studying the following parameters effect.

In fact, similar studies revealed that the majority of pollutants are reduced in the first minutes of reaction $[13,29]$, because of the availability of sulfate radicals produced during the reaction (7) that oxidizes organic

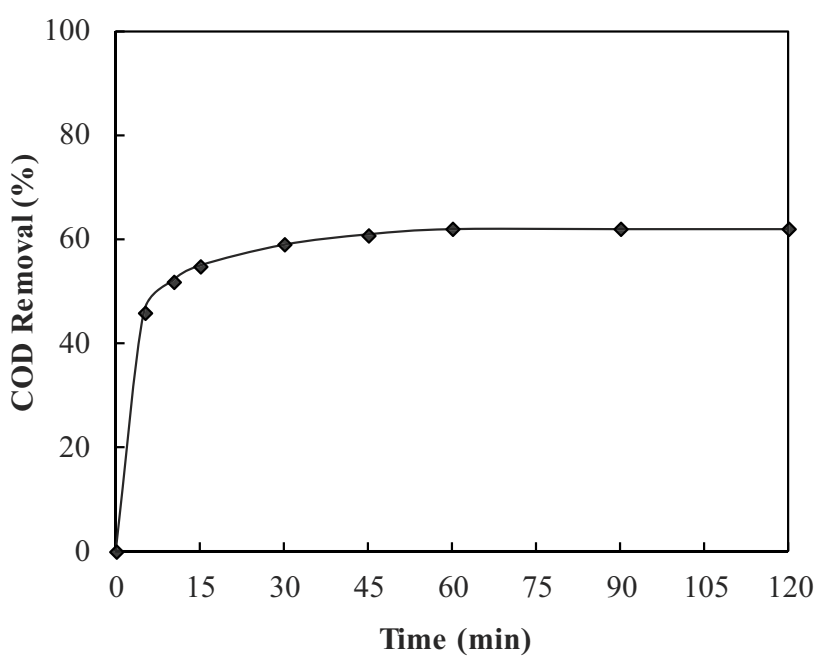

Fig. 2 COD removal depending on contact time: $[\mathrm{PS}]=3000 \mathrm{mg} \mathrm{L}^{-1} ;\left[\mathrm{Fe}^{2+}\right]=1000 \mathrm{mg} \mathrm{L}^{-1}$; solution $\mathrm{pH}=3$ 
contaminants [30, 31]. Furthermore, the organic matter could be degraded by hydroxyl radicals $(\cdot \mathrm{OH})$ which are produced through the reaction of $\mathrm{SO}_{4}^{--}$with $\mathrm{H}_{2} \mathrm{O}$ and/or $\mathrm{OH}^{-}$according to the reactions (8) and (9) [32-35].

$$
\begin{aligned}
& \mathrm{S}_{2} \mathrm{O}_{8}^{2-}+\mathrm{Fe}^{2+} \rightarrow \mathrm{Fe}^{3+}+\mathrm{SO}_{4}^{2-}+\mathrm{SO}_{4}^{-} \\
& \mathrm{SO}_{4}^{-\cdot}+\mathrm{H}_{2} \mathrm{O} \rightarrow \mathrm{OH}+\mathrm{SO}_{4}^{2-}+\mathrm{H}^{+} \\
& \mathrm{SO}_{4}^{-\cdot}+\mathrm{OH}^{-} \rightarrow \mathrm{OH}+\mathrm{SO}_{4}^{2-}
\end{aligned}
$$

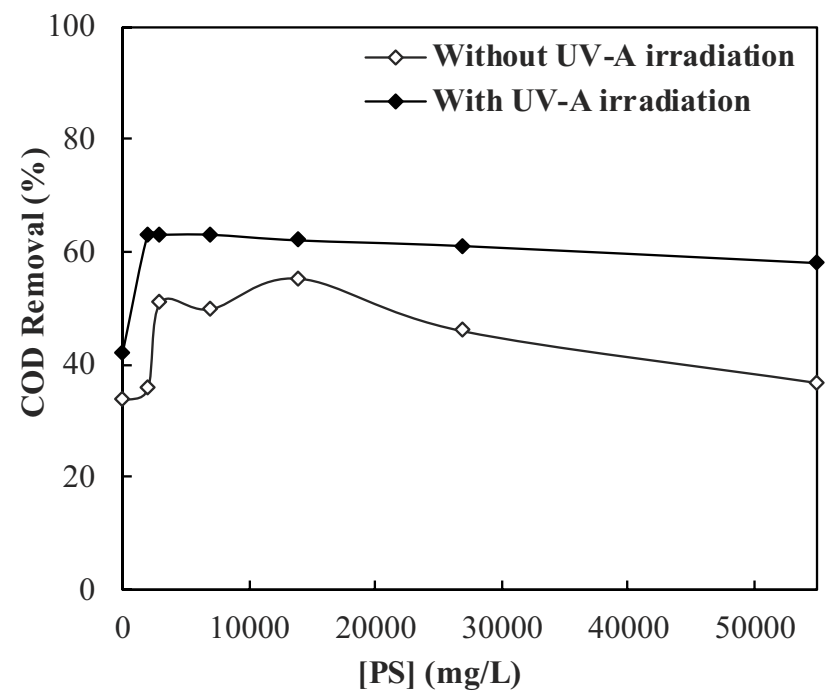

Fig. 3 Effect of PS dosage on COD removal (with and without UV-A irradiation): $\left[\mathrm{Fe}^{2+}\right]=200 \mathrm{mg} \mathrm{L}^{-1}$; solution $\mathrm{pH}=3$; contact time $=60 \mathrm{~min}$

\subsection{PS dosage effect}

In order to explore the PS dose influence on process efficacy in terms of COD removal (Fig. 3), PS dose was varied between 0 and $55,000 \mathrm{mg} \mathrm{L}^{-1}$. Thus, increasing PS dosage from 0 to $3000 \mathrm{mg} \mathrm{L}^{-1}$ enhanced COD removal from 34 to $51 \%$ in dark conditions, however, it increased from 42 to $63 \%$ with UV-A light.

In fact, several studies have proved that UV-A irradiation enhances the PS decomposition into sulfate radicals (3), which have powerful effects on the organic compounds oxidation $[12,33,36]$, following the proposed mechanism presented in Fig. 4.

However, rising the PS dose to $55,000 \mathrm{mg} \mathrm{L}^{-1}$ decreased slightly the efficiency of the process to $58 \%$ for irradiated sample, though it reached $37 \%$ for non-irradiated one. Similarly, several studies indicated that above an optimal persulfate dosage, the sulfate radicals could react with the excess quantity of PS (reaction 10), or they react with themselves (reaction 11), or with the catalyst $\mathrm{Fe}^{2+}$ (reaction 12), which inhibits the oxidation of organic compounds $[13,28,31,37]$. Hence, $1400 \mathrm{mg} \mathrm{L}^{-1}$ was fixed as the optimal concentration of persulfate ions.

$\mathrm{SO}_{4}^{-\cdot}+\mathrm{S}_{2} \mathrm{O}_{8}^{2-} \rightarrow \mathrm{SO}_{4}^{2-}+\mathrm{S}_{2} \mathrm{O}_{8}^{2-}$

$\mathrm{SO}_{4}^{-\cdot}+\mathrm{SO}_{4}^{-\cdot} \rightarrow 2 \mathrm{SO}_{4}^{2-}$

$\mathrm{SO}_{4}^{-\cdot}+\mathrm{Fe}^{2+} \rightarrow \mathrm{Fe}^{3+}+\mathrm{SO}_{4}^{2-}$

Figure 5 presents the evolution of UV-Vis spectra of leachate samples according to PS dosages. The results, as shown in Fig. 5, indicate that varying PS dose from 0 to $14,000 \mathrm{mg} \mathrm{L}^{-1}$ significantly reduced the absorbance values in the range of $250-300 \mathrm{~nm}$ which is characteristic of the presence of organic matter, especially aromatic

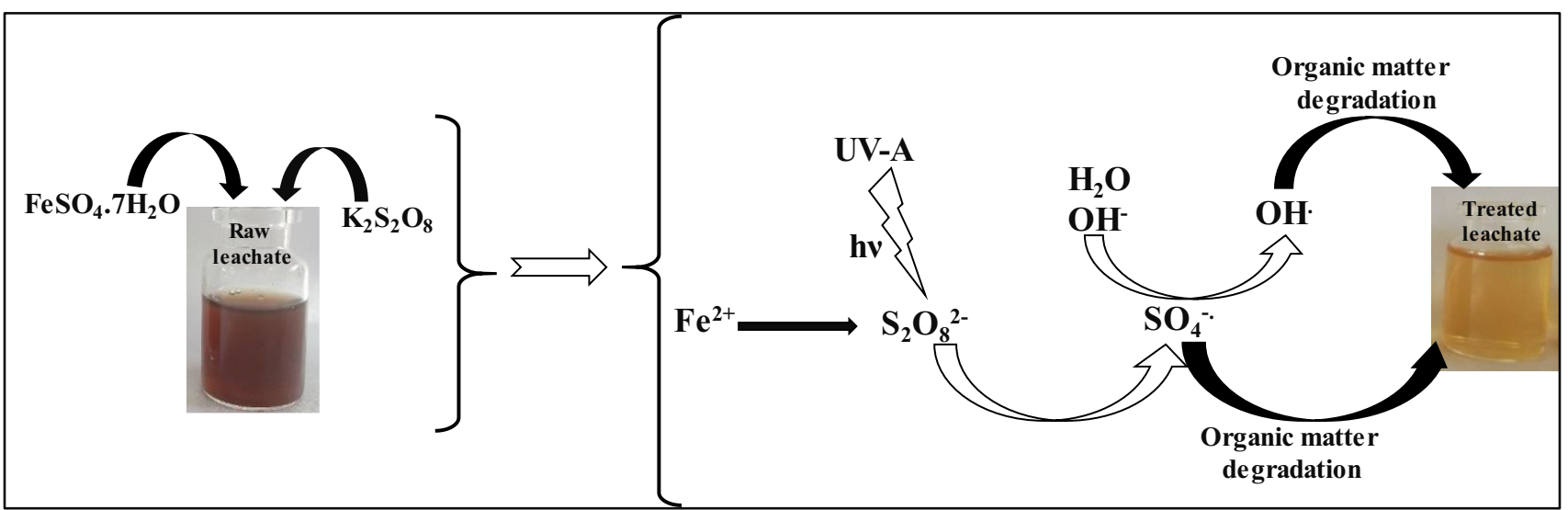

Fig. 4 Proposed mechanism for the organic matter degradation using activated Persulfate by $\mathrm{Fe}^{2+}$ and UV-A irradiation 


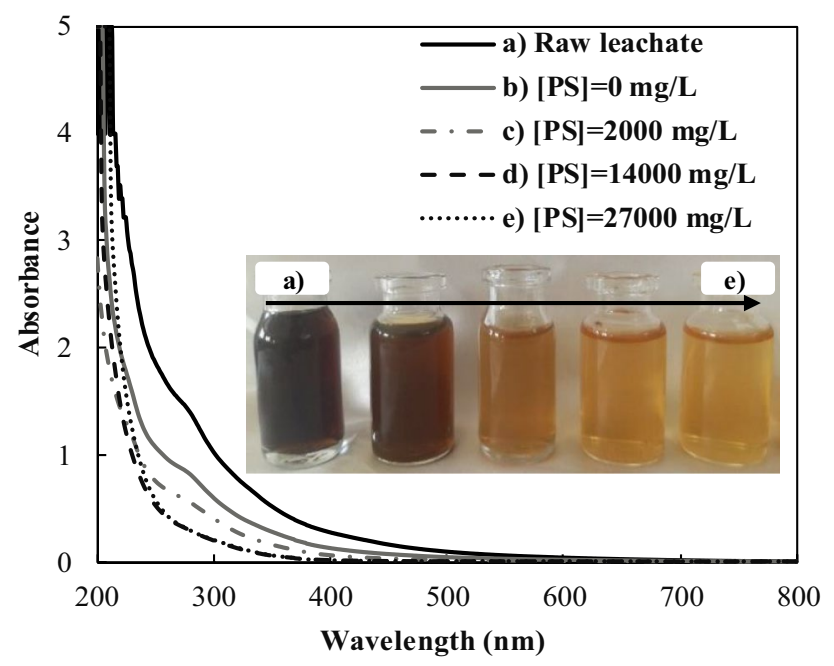

Fig. 5 Effect of PS dosage on UV-Vis spectrum (with UV-A irradiation)

compounds, hydrocarbons and humic acids [38, 39]. The decrease of the absorbance values correlates with the variation of COD removal presented in Fig. 3 [40, 41], indicating the evolution of the organic matter degradation at different PS dosages.

\section{3 $\mathrm{Fe}^{2+}$ dosage effect}

After optimizing PS dosage at $14,000 \mathrm{mg} \mathrm{L}^{-1}$, the effect of $\mathrm{Fe}^{2+}$ dosage was investigated in a range of $0-3000 \mathrm{mg} \mathrm{L}^{-1}$ in terms of COD removal (Fig. 6) and UV-Vis spectrum variation (Fig. 7).

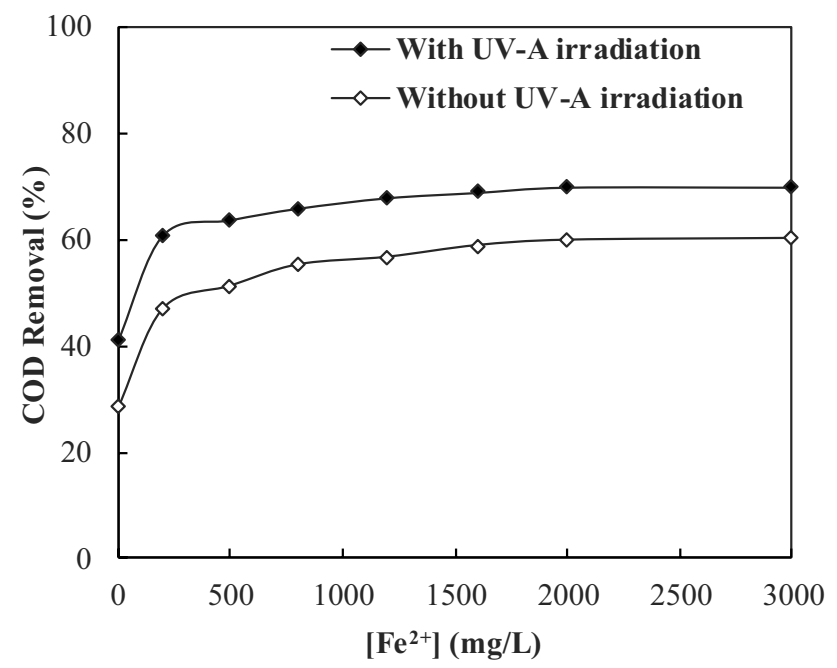

Fig. 6 Effect of $\mathrm{Fe}^{2+}$ dosage on COD removal (with and without UV-A irradiation): $[P S]=14,000 \mathrm{mg} \mathrm{L}^{-1} ; \mathrm{pH}=3$; contact time $=60 \mathrm{~min}$

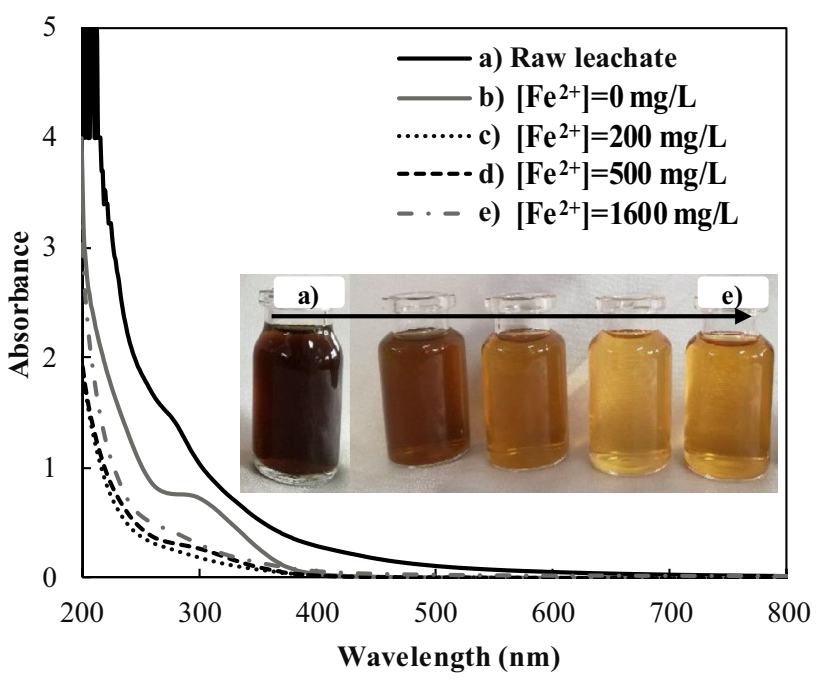

Fig. 7 Effect of $\mathrm{Fe}^{2+}$ dosage on UV-Vis spectrum (with UV-A irradiation)

As shown in Fig. 6, increasing the ferrous ions amount has a positive impact on COD reduction for both treatments (with and without UV-A irradiation). For non-irradiated sample, varying $\mathrm{Fe}^{2+}$ dose from 0 to $200 \mathrm{mg} \mathrm{L}^{-1}$ improved COD removal from 29 to $47 \%$. The same evolution was noticed for the irradiated sample where the process efficacy enhanced from 41 to $61 \%$. Afterwards, an additional COD removal was obtained $(+10 \%)$ when further $\mathrm{Fe}^{2+}$ amount was added.

These results are in agreement with similar findings, which proved that under the UV irradiations, persulfate can be promptly transformed into two sulfate radical anions $\left(\mathrm{SO}_{4}^{--}\right)$following the reaction (3) [42-45].

Moreover, a considerable decrease of the UV-Visible absorbance in the range $250-300 \mathrm{~nm}$ with increasing the amount of ferrous ions from 0 to $1600 \mathrm{mg} \mathrm{L}^{-1}$, is observed in Fig. 7 which confirms the significant positive effect of $\mathrm{Fe}^{2+}$ addition on the process mechanism for the organic matter degradation [46]. Consequently, the optimal $\mathrm{Fe}^{2+}$ dosage was fixed at $1600 \mathrm{mg} \mathrm{L}^{-1}$.

Such positive effect of metal catalysts on organic pollutants oxidation has been previously demonstrated [6, $21,30]$, especially that $\mathrm{Fe}^{2+}$ is an effective PS activator favoring then the production of sulfate radicals following the reaction 12 and presented by the mechanism in Fig. 4. However, exceeding the optimal dosage could negatively affect the treatment efficiency $[47,48]$, due to the sulfate radicals consumption by the excess of $\mathrm{Fe}^{2+}$ ions through (reaction 11). 


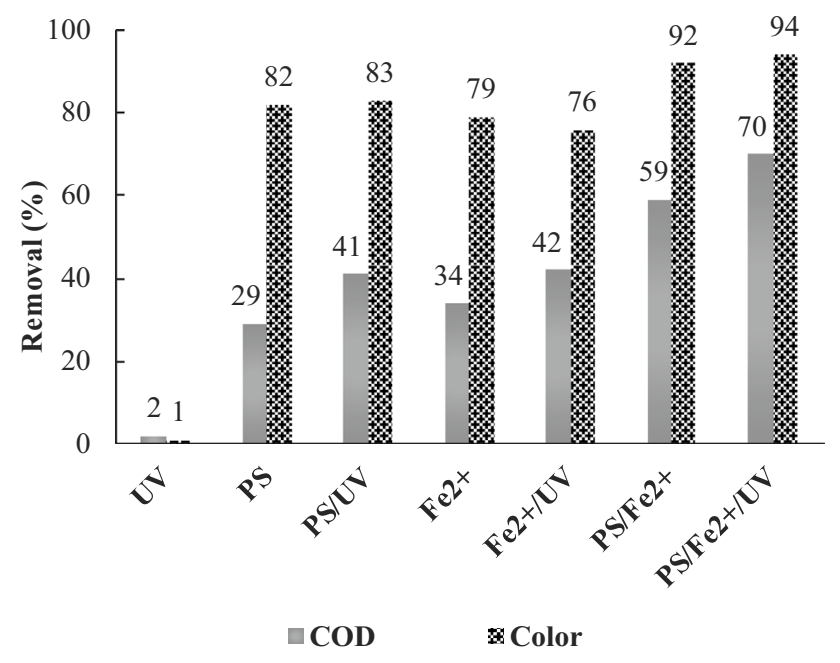

Fig. $8 \mathrm{COD}$ and color removal depending on different combinations of $\left([\mathrm{PS}]=14,000 \mathrm{mg} \mathrm{L}^{-1} ;\left[\mathrm{Fe}^{2+}\right]=1600 \mathrm{mg} \mathrm{L}^{-1}\right)$

\subsection{Optimized conditions}

Figure 8 summarizes the COD and color removal efficiencies obtained by different treatment combinations of $\mathrm{Fe}^{2+}, \mathrm{PS}$ and UV. Hence, the following order PS/Fe ${ }^{2+} /$ $\mathrm{UV}>\mathrm{PS} / \mathrm{Fe}^{2+}>\mathrm{Fe}^{2+} / \mathrm{UV}>\mathrm{PS} / \mathrm{UV}>\mathrm{Fe}^{2+}>\mathrm{PS}>\mathrm{UV}$ is noticed in terms of COD removal, while this order $\mathrm{PS} / \mathrm{Fe}^{2+} / \mathrm{UV}>\mathrm{PS} /$ $\mathrm{Fe}^{2+}>\mathrm{PS} / \mathrm{UV}>\mathrm{PS}>\mathrm{Fe}^{2+}>\mathrm{Fe}^{2+} / \mathrm{UV}>\mathrm{UV}$ was deducted in terms of color removal.

This result showed that the combined system (i.e., PS/ $\mathrm{Fe}^{2+} / \mathrm{UV}$ ) was efficient for COD and color removal compared with other studied processes.

On the basis of the previous results, it could be concluded that the optimum conditions for the studied landfill leachate treatment are: $\mathrm{pH}=3$, reaction time $=60 \mathrm{~min}$, $[\mathrm{PS}]=14,000 \mathrm{mg} \mathrm{L}^{-1}$ and $\left[\mathrm{Fe}^{2+}\right]=1600 \mathrm{mg} \mathrm{L}^{-1}$ under UV-A irradiations. Hence, a remarkable treatment efficacy is noticed in the image of sample leachate before and after treatment under the optimum operating conditions (Fig. 9).

\section{Conclusion}

Based on the results of this research work, it was evident that $\mathrm{PS} / \mathrm{Fe}^{2+} / \mathrm{UV}-\mathrm{A}$ system was successfully applied for removing the chemical oxygen demand (COD) of stabilized leachate. The results revealed that the efficiency of $\mathrm{PS} / \mathrm{Fe}^{2+} / \mathrm{UV}-\mathrm{A}$ system with respect to the COD removal was influenced by several operational parameters which included the dosage of $\mathrm{PS}, \mathrm{Fe}^{2+}$, and reaction time. At optimum conditions of $\mathrm{PS} / \mathrm{Fe}^{2+} / \mathrm{UV}-\mathrm{A}$ and $\mathrm{PS} / \mathrm{Fe}^{2+}$ processes $\left(14,000 \mathrm{mg} \mathrm{L}^{-1}\right.$ of $\mathrm{S}_{2} \mathrm{O}_{8}{ }^{2-}, 1600 \mathrm{mg} \mathrm{L}^{-1}$ of $\mathrm{Fe}^{2+}$, and $\mathrm{pH}=3$

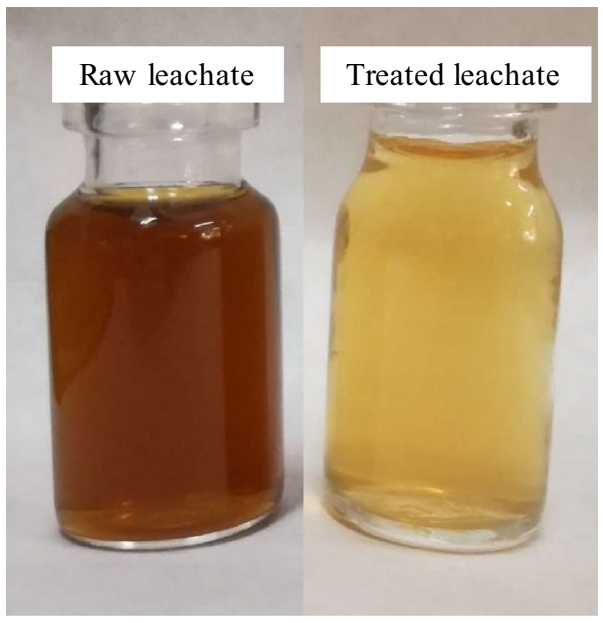

Fig. 9 Pictures of raw and treated leachate by $\mathrm{PS} / \mathrm{Fe}^{2+} / \mathrm{UV}-\mathrm{A}$ process

for 60 min of reaction time), maximumCOD removals were found $70 \%$ and $59 \%$, respectively. It was also demonstrated that the optimization of each reagent dosage is highly required to avoid the inhibition of sulfate radicals production.

Indeed, the promising findings presented in this paper will provide further studies in order to maximize the treatment performance by testing other activators of persulfate or by coupling this process with other treatments. Especially that landfill leachate is known by its refractory and complex compounds.

Finally, it can be concluded that $\mathrm{PS} / \mathrm{Fe}^{2+} / \mathrm{UV}$ system could be considered as a new competitive and efficient process for leachate treatment in Morocco in comparison with other processes treatment previously studied.

Funding This work was not had any grant a funding from any Organization or Institution.

\section{Compliance with ethical standards}

Conflict of interest The authors declare that they have no conflict of interest.

\section{References}

1. Kachabi M, El Mrabet I, Benchekroun Z, Nawdali M, Zaitan H (2019) Synthesis and adsorption properties of activated carbon from $\mathrm{KOH}$-activation of Moroccan Jujube shells for the removal of COD and color from wastewater. Mediterr J Chem 8:168-178. https://doi.org/10.13171/10.13171/MJC8319050704HZ

2. Youcai Z (2018) Chapter 3-biological treatment processes for leachate. In: Pollution control technology for leachate from municipal solid waste. Elsevier, Amsterdam, pp 185-324

\section{SN Applied Sciences}


3. Awual R, Hasan M, Asiri AM, Rahman MM (2019) Novel optical composite material for efficient vanadium(III) capturing from wastewater. J Mol Liq 283:704-712. https://doi.org/10.1016/j. molliq.2019.03.119

4. Shahat A, Hassan HMA, El-Shahat MF, El Shahawy O, Awual $\mathrm{R}$ (2018) Visual nickel(II) ions treatment in petroleum samples using a mesoporous composite adsorbent. Chem Eng J 334:957-967. https://doi.org/10.1016/j.cej.2017.10.105

5. Chaouki Z, Khalil F, Ijjaali M, Valdés H, Rafqah S, Sarakha M, Zaitan H (2017) Use of combination of coagulation and adsorption process for the landfill leachate treatment from Casablanca city. Desalin Water Treat 83:262-271. https://doi. org/10.5004/dwt.2017.20743

6. Deng Y, Zhao R (2015) Advanced oxidation processes (AOPs) in wastewater treatment. Curr Pollut Rep 1:167-176. https:// doi.org/10.1007/s40726-015-0015-z

7. El Mrabet I, Kachabi M, Nawdali M, Harrach A, Khalil F, Ijjaali M, Benzina M, Zaitan H (2018) Treatment of landfill leachate from Fez city (Morocco) using Fenton and photo-Fenton processes. IOP Conf Ser Earth Environ Sci 161:1-10. https://doi. org/10.1088/1755-1315/161/1/012025

8. Göde JN, Hoe D, Trevisan V, Skoronski E (2019) Application of the Fenton and Fenton-like processes in the landfill leachate tertiary treatment. J Environ Chem Eng 7:103352. https://doi. org/10.1016/j.jece.2019.103352

9. Oloibiri V, Ufomba I, Chys M, Audenaert WTM, Demeestere K, Van Hulle SWH (2015) A comparative study on the efficiency of ozonation and coagulation-flocculation as pretreatment to activated carbon adsorption of biologically stabilized landfill leachate. Waste Manag 43:335-342. https://doi.org/10.1016/j. wasman.2015.06.014

10. Tiwari A, Shukla A, Tiwari D, Lee S (2018) Au-nanoparticle/ Nanopillars $\mathrm{TiO}_{2}$ meso-porous thin films in the degradation of tetracycline using UV-A light. J Ind Eng Chem 69:141-152. https://doi.org/10.1016/j.jiec.2018.09.027

11. Amr SSA, Alkarkhi AFMM, Alslaibi TM, Abujazar MSS (2018) Performance of combined persulfate/aluminum sulfate for landfill leachate treatment. Data Br 19:951-958. https://doi. org/10.1016/j.dib.2018.05.111

12. Poblete R, Oller I, Maldonado MI, Cortes E (2019) Improved landfill leachate quality using ozone, UV solar radiation, hydrogen peroxide, persulfate and adsorption processes. J Environ Manag 232:45-51. https://doi.org/10.1016/j.jenvm an.2018.11.030

13. Asha TT, Gandhimathi R, Ramesh ST, Nidheesh PV (2017) Treatment of stabilized leachate by ferrous-Activated persulfate oxidative system. J Hazardous, Toxic, Radioact Waste 21:1-6. https ://doi.org/10.1061/(ASCE)HZ.2153-5515.0000328

14. Tripathy BK, Kumar M (2019) Sequential coagulation/flocculation and microwave-persulfate processes for landfill leachate treatment: Assessment of bio-toxicity, effect of pretreatment and cost-analysis. Waste Manag 85:18-29. https://doi. org/10.1016/j.wasman.2018.12.014

15. Silveira JE, Zazo JA, Pliego G, Casas JA (2018) Landfill leachate treatment by sequential combination of activated persulfate and Fenton oxidation. Waste Manag 81:220-225. https://doi. org/10.1016/j.wasman.2018.10.007

16. Zhong $\mathrm{H}$, Tian $Y$, Yang Q, Brusseau ML, Yang L, Zeng G (2017) Degradation of landfill leachate compounds by persulfate for groundwater remediation. Chem Eng J 307:399-407. https:// doi.org/10.1016/j.cej.2016.08.069

17. Kolthoff IM, Stenger V (1947) Volumetric analysis, Second Revised Ed Titration Methods: acid-base, precipitation, and complex reactions, vol. II. Interscience Publishers, Inc., New York

18. House DA (1962) Kinetics and mechanism of oxidations by peroxydisulfate. Chem Rev 62:185-203
19. Chen W, Luo Y, Ran G, Li Q (2019) An investigation of refractory organics in membrane bioreactor effluent following the treatment of landfill leachate by the $\mathrm{O}_{3} / \mathrm{H}_{2} \mathrm{O}_{2}$ and MW/PS processes. Waste Manag 97:1-9. https://doi.org/10.1016/j.wasma n.2019.07.016

20. Guvenc SY (2019) Optimization of COD removal from leachate nanofiltration concentrate using $\mathrm{H}_{2} \mathrm{O}_{2} / \mathrm{Fe}^{+2} /$ heat - activated persulfate oxidation processes. Process Saf Environ Prot 126:7-17. https://doi.org/10.1016/j.psep.2019.03.034

21. Zhang $M$, Chen $X$, Zhou $H$, Murugananthan $M$, Zhang $Y$ (2015) Degradation of $p$-nitrophenol by heat and metal ions co-activated persulfate. Chem Eng J 264:39-47. https://doi. org/10.1016/j.cej.2014.11.060

22. Assou M, El Fels L, El Asli A, Fakidi H, Souabi S, Hafidi M (2016) Landfill leachate treatment by a coagulation-flocculation process : effect of the introduction order of the reagents. Desalin Water Treat 57:21817-21826. https://doi.org/10.1080/19443 994.2015.1127779

23. Abouri M, Chanaa I, Souabi S, Qachach H, Jada A (2018) Diagnostic and Treatment of leachate from municipal solid waste in morocco using experimental design methodology. In: Recent advances in environmental science from the Euro-mediterranean and surrounding regions. EMCEI 2017. Advances in Science, Technology and Innovation. Springer, New York, pp 985-987

24. Abouri M, Souabi S, Bahlaoui MA, Zouhir F, Baudu M, Moharram R, Pala A (2016) Aerobic treatment of leachate from municipal solid waste in Morocco. In: Waste and resource managementproceedings of the institution of civil engineers. pp 92-100

25. Amor C, De T-S, Peres JA, Maldonado MI, Oller I, Malato S, Lucas MS (2015) Mature landfill leachate treatment by coagulation/ flocculation combined with Fenton and solar photo-Fenton processes. J Hazard Mater 286:261-268. https://doi.org/10.1016/j. jhazmat.2014.12.036

26. Kulikowska M, Zielińska K, Konopka D (2018) Treatment of stabilized landfill leachate in an integrated adsorption-fine-ultrafiltration system. Int J Environ Sci Technol 16:423-430. https:// doi.org/10.1007/s13762-018-1685-z

27. Tizaoui C, Bouselmi L, Mansouri L, Ghrabi A (2007) Landfill leachate treatment with ozone and ozone/hydrogen peroxide systems. J Hazard Mater 140:316-324. https://doi.org/10.1016/j. jhazmat.2006.09.023

28. Yuan X, Guan R, Wu Z, Jiang L, Li Y, Chen X, Zeng G (2018) Effective treatment of oily scum via catalytic wet persulfate oxidation process activated by $\mathrm{Fe}^{2+}$.J Environ Manage 217:411-415. https ://doi.org/10.1016/j.jenvman.2018.03.129

29. Chakma S, Praneeth S, Moholkar VS (2017) Mechanistic investigations in sono-hybrid (ultrasound/Fe ${ }^{2+} / \mathrm{UVC}$ ) techniques of persulfate activation for degradation of Azorubine. Ultrason Sonochem 38:652-663. https://doi.org/10.1016/j.ultso nch.2016.08.015

30. Oh SY, Kim HW, Park JM, Park HS, Yoon C (2009) Oxidation of polyvinyl alcohol by persulfate activated with heat, $\mathrm{Fe}^{2+}$, and zero-valent iron. J Hazard Mater 168:346-351. https://doi. org/10.1016/j.jhazmat.2009.02.065

31. Matzek LW, Carter KE (2016) Activated persulfate for organic chemical degradation: a review. Chemosphere 151:178-188. https://doi.org/10.1016/j.chemosphere.2016.02.055

32. Carra I, Sánchez Pérez JA, Malato $S$, Autin $O$, Jefferson $B$, Jarvis $P$ (2016) Performance of different advanced oxidation processes for tertiary wastewater treatment to remove the pesticide acetamiprid. J Chem Technol Biotechnol 91:72-81. https://doi. org/10.1002/jctb.4577

33. Bekkouche S, Merouani S, Hamdaoui O, Bouhelassa M (2017) Efficient photocatalytic degradation of Safranin $\mathrm{O}$ by integrating solar-UV/TiO $2 /$ persulfate treatment: Implication of sulfate 
radical in the oxidation process and effect of various water matrix components. J Photochem Photobiol A Chem 345:80-91. https://doi.org/10.1016/j.jphotochem.2017.05.028

34. Oh W-D, Dong Z, Lim T-T (2016) Generation of sulfate radical through heterogeneous catalysis for organic contaminants removal: Current development, challenges and prospects. Appl Catal B Environ 194:169-201. https://doi.org/10.1016/j.apcat b.2016.04.003

35. Sun $\mathrm{H}$, Wang S (2015) Catalytic oxidation of organic pollutants in aqueous solution using sulfate radicals. Catalysis, vol 27. The Royal Society of Chemistry, Netherlands, pp 209-247

36. Ioannidi A, Frontistis Z, Mantzavinos D (2018) Destruction of propyl paraben by persulfate activated with UV-A light emitting diodes. J Environ Chem Eng 6:2992-2997. https://doi. org/10.1016/j.jece.2018.04.049

37. Fu Y, Wu G, Geng J, Li J, Li S, Ren H (2018) Kinetics and modeling of artificial sweeteners degradation in wastewater by the UV/persulfate process. Water Res 150:12-20. https://doi. org/10.1016/j.watres.2018.11.051

38. Zhou Y, Xie Y, Wang M, Zou F, Zhang C, Guan Z, Yan M (2019) In-situ characterization of dissolved organic matter removal by coagulation using differential UV-Visible absorbance spectroscopy. Chemosphere 242:125062. https://doi.org/10.1016/j. chemosphere.2019.125062

39. Yazdani MR, Duimovich N, Tiraferri A, Laurell P, Borghei M, Zimmerman JB, Vahala R (2019) Tailored mesoporous biochar sorbents from pinecone biomass for the adsorption of natural organic matter from lake water. J Mol Liq 291:111248. https:// doi.org/10.1016/j.molliq.2019.111248

40. Thomas O, Junqua G, Thomas M-F (2017) Chapter 11: leachates and organic extracts from solids. In: UV-visible spectrophotometry of water and wastewater. Elsevier, Amsterdam, pp 349-378

41. Thomas O, Theraulaz F, Vaillant S, Pouet M-F (2007) Chapter 8: urban wastewater. In: Techniques and instrumentation in analytical chemistry. Elsevier, Amsterdam, pp 189-216

42. Gao Y, Gao N, Yin D, Tian F, Zheng Q (2018) Oxidation of the B-blocker propranolol by UV/persulfate: effect, mechanism and toxicity investigation. Chemosphere 201:50-58. https:// doi.org/10.1016/j.chemosphere.2018.02.158

43. Hou S, Ling L, Shang C, Guan Y, Fang J (2017) Degradation kinetics and pathways of haloacetonitriles by the UV/persulfate process. Chem Eng J 320:478-484. https://doi.org/10.1016/j. cej.2017.03.042

44. Fu Y, Li S, Shi Y, Geng J, Li J, Wu G, Xu K, Ren H (2019) Removal of artificial sweeteners using UV/persulfate: radical-based degradation kinetic model in wastewater, pathways and toxicity. Water Res 167:115102. https://doi.org/10.1016/j.watre s.2019.115102

45. Ishak AR, Hamid FS, Mohamad S, Tay KS (2018) Stabilized landfill leachate treatment by coagulation-flocculation coupled with UV-based sulfate radical oxidation process. Waste Manag 76:575-581. https://doi.org/10.1016/j.wasman.2018.02.047

46. Touraud E, Roussy J, Domeizel M, Junqua G, Thomas O (2007) Chapter 10: leachates and organic extracts from solids. In: Techniques and instrumentation in analytical chemistry. Elsevier, Amsterdam, pp 243-265

47. Wang X, Wang L, Li J, Qiu J, Cai C, Zhang H (2014) Degradation of acid orange 7 by persulfate activated with zero valent iron in the presence of ultrasonic irradiation. Sep Purif Technol 122:41-46. https://doi.org/10.1016/j.seppur.2013.10.037

48. Vicente F, Santos A, Romero A, Rodriguez S (2011) Kinetic study of diuron oxidation and mineralization by persulphate: effects of temperature, oxidant concentration and iron dosage method. Chem Eng J 170:127-135. https://doi.org/10.1016/j. cej.2011.03.042

Publisher's Note Springer Nature remains neutral with regard to jurisdictional claims in published maps and institutional affiliations. 